\title{
Application of Concept Mapping to Improve Critical Thinking Ability of Human Digestive Material in Grade V Students
}

\author{
Sonta Asilsa Faisalina \\ SDN Ngarus 02 Pati \\ faisalina.sonta@gmail.com
}

\section{Article History}

accepted 01/11/2020

published 15/11/2020

\begin{abstract}
The purpose of this study was to improve student learning outcomes in thematic learning class $\checkmark$ SDN Ngarus 02 Pati. This research is a classroom action research (PTK) which is carried out in four cycles, each cycle consisting of the planning, implementation, observation and reflection stages. The subjects of this study were class $V$ students of SDN Ngarus 02 Pati for the 2020/2021 academic year, totaling 36 students. Data collection techniques used tests and nontests. Data analysis includes data reduction, data presentation, and drawing conclusions. Research shows that the application of concept mapping to improve critical thinking skills in class V SDN Ngarus 02 Pati as evidenced by the percentage of completeness of learning outcomes in the pre-cycle from $17 \%$ to $40 \%$ in cycle I, to $52 \%$ in cycle II, and to $75 \%$ in cycle III. And the percentage of critical thinking in the pre-cycle is $63 \%$ to $65 \%$ in the first cycle, to $66 \%$ in the second cycle, and $67 \%$ in the third cycle.
\end{abstract}

Keywords: critical thinking, concept mapping, learning outcomes

\begin{abstract}
Abstrak
Tujuan penelitian ini adalah meningkatkan hasil belajar siswa pada pembelajaran tematik kelas V SDN Ngarus 02 Pati. Penelitian ini merupakan penelitian tindakan kelas (PTK) yang dilaksanakan dalam empat siklus, setiap siklus terdiri dari tahap perencanaan, pelaksanaan, observasi, dan refleksi. Subjek penelitian ini adalah peserta didik kelas V SDN Ngarus 02 Pati tahun pelajaran 2020/2021 yang berjumlah 36 peserta didik. Teknik pengumpulan data menggunakan tes dan non tes. Analisis data meliputi reduksi data, penyajian data, dan penarikan kesimpulan. Penelitian menunjukkan bahwa penerapan concept mapping untuk meningkatkan kemampuan berpikir kritis pada kelas V SDN Ngarus 02 Pati yang dibuktikan dengan persentase ketuntasan hasil belajar pada pra siklus sebesar $17 \%$ menjadi $40 \%$ pada siklus I, menjadi $52 \%$ pada siklus II, dan menjadi $75 \%$ pada siklus III. Serta presentase berpikir kritis pada pra siklus sebesar $63 \%$ menjadi $65 \%$ pada siklus I, menjadi $66 \%$ pada siklus II, dan menjadi $67 \%$ pada siklus III.
\end{abstract}

Kata kunci: berpikir kritis, concept mapping, hasil belajar

Social, Humanities, and Education Studies (SHEs): Conference Series https://jurnal.uns.ac.id/shes 


\section{PENDAHULUAN}

Perkembangan teknologi informasi dan komunikasi di era industri 4.0 telah memberi pengaruh yang besar terhadap proses pengajaran dan pembelajaran. Orientasi pembelajaran yang berpusat pada peserta didik telah berubah menjadi pembelajaran kolaborasi antara peserta didik dan guru. Dalam hal ini, guru dituntut kreatif dan inovatif terhadap penyampaian materi secara daring. Pemilihan metode, media, platform akan sangat berpengaruh terhadap motivasi belajar peserta didik, dimana motivasi peserta didik erat kaitannya dengan hasil belajar.

Proses pembelajaran di kelas hendaknya melibatkan siswa untuk berproses sehingga mereka akan dengan mudah memahami konsep. Pembelajaran IImu Pengetahuan Alam di Sekolah Dasar seharusnya menjadi pembelajaran yang menarik dan menyenangkan bagi peserta didik. Pembelajaran IPA sebaiknya dilaksanakan melalui pengamatan dan percobaan bukan hanya teori yang panjang di dalam kelas. Melalui pengamatan dan percobaan akan membuat siswa menjadi aktif di dalam kelas dan mereka menjadi lebih paham terhadap materi yang diajarkan karena mereka mengalaminya sendiri. Hal tersebut juga akan menumbuhkan rasa ingin tahu yang besar dari dalam diri peserta didik dan mengajarkan mereka untuk berpikir kritis menghadapu masalah-masalah yang ada yang berhubungan dengan pelajaran IPA. Siswa juga akan sering bertanya kepada guru terhadap hal-hal yang belum diketahui dan mereka akan berusaha mencari jawaban dari masalah yang dihadapi. Dengan demikian cara berpikir siswa akan berkembang kritis, obyektif dan kreatif dan kreatif dalam menghadapi berbagai kesenjangan yang terjadi. Sebenanrnya permasalahan peserta didik pada kemampuan berpikir kritis bukan terletak pada susahnya materi tetapi pada strategi pembelajaran yang dilakukan oleg guru. Guru harus mengembangkan pembelajaran berinovasi dengan menggunakan metode tertentu dalam proses pembelajaran untuk meningkatkan keberhasilan belajar siswa.

Peningkatkan keberhasilan belajar siswa diantaranya dapat dilakukan melalui upaya memperbaiki proses pembelajaran. Dalam perbaikan proses pembelajaran ini peranan guru sangat penting, yaitu menyajikan bahan pembelajaran yang tepat. Dalam hal ini, maka harus bisa menciptakan situasi pembelajaran yang memerlukan keaktifan siswa dan guru secara fisik, mental, emosional bahkan moral dan spiritual ( Tafsir dalam Suryatna dan Sudardja Adiwikarta 2013: 3). Sedangkan pembelajaran yang inovatif adalah sebagai berikut :

"Pembelajaran inovatif artinya pembelajaran yang menggunakan segala aspek (metode, bahan, perangkat, dan sebagainya) yang dipandang baru atau bersifat inovatif. Artinya berbeda atau belum pernah dilaksanakan oleh seorang guru meskipun semua itu bukan barang baru bagi guru lain. Pembelajaran inovatif artinya guru selalu berusaha memperbarui baik metode mengajar maupun materi pembelajarannya" (Tafsir dalam Suryatna, Yayat dan Sudardja Adiwikarta, 2013: $3)$.

Proses pembelajaran yang dikembangkan di Indonesia sangat menuntut siswa untuk terlibat secara aktif dalam proses kegiatan belajar mengajar sehingga kemampuan pemecahan masalahnya menjadi lebih berkembang. Terkait dengan aspek kemampuan pemecahan masalah dalam pembelajaran dituntut siswa untuk memiliki suatu kemampuan berpikir yang lebih tinggi, hal ini dikarenakan berpikir merupakan suatu aktivitas mental yang dilakukan seseorang untuk membantu merumuskan atau memecahkan masalah dan membuat keputusan yang tepat sesuai dengan yang dinginkannya (Harjanto, 2011).

Pada kondisi awal kenyataannya, dilihat dari hasil evaluasi peserta didik kelas $\mathrm{V}$ masih terlihat rendah. Pembelajaran yang diberikan guru belum menuntut peserta didik untuk berpikir kritis menjadi salah satu penyebabnya. Dengan kondisi ini, peneliti 
memanfaatkan metode concept mapping untuk meningkatkan kemampuan berfikir kritis.

Berdasarkan masalah di atas, sangat dibutuhkan inovasi pada pembelajaran IPA agar dapat mengembangkan kemampuan berpikir siswa secara optimal, terutama kemampuan berpikir kritis. Metode pembelajaran Concept Mapping merupakan salah satu tipe dari pembelajaran kooperatif yang dapat digunakan untuk memberikan motivasi peserta didik supaya berminat mempelajari IPA khususnya pada materi sistem gerak pada manusia. Dengan metode Concept Mapping diharapkan peserta didik lebih aktif, lebih kritis dalam menyelesaikan masalah dan lebih bertanggung jawab terhadap tugas yang diberikan, hal ini sesuai dengan dengan penelitian Naim (2009) menunjukkan bahwa Mind Mapping dapat meningkatkan kemampuan siswa dalam berpikir karena memadukan dan mengembangkan potensi kerja otak, sehingga perhatian terpusat pada subjek serta mampu mengembangkan cara pengaturan pikiran secara terperinci.

Permasalahan yang ditemukan yaitu guru kurang memahami langkah-langkah pembelajaran tematik yang menyenangkan, penerapan metode kurang maksimal, media yang kurang menarik, siswa kurang dalam kemampuan berpikir kritis, siswa kurang termotivasi dalam pembelajaran.

Berdasarkan identifikasi masalah di atas maka rumusan masalah dalam penelitian ini adalah sebagai berikut : "Bagaimana Metode Concept Mapping akan Meningkatkan Kemampuan Berpikir Kritis pada Materi Sistem Pencernaan Manusia? Adapun tujuan penelitian ini adalah medeskripsikan langkah-langkah penerapan concept mapping sebagai metode pembelajaran dan mengetahui peningkatan kemampuan berpikir kritis peserta didik melalui penerapan metode concept mapping.

\section{METODE}

Penelitian ini merupakan penelitian tindakan kelas (PTK) kolaboratif yang dilaksanakan dalam empat siklus, setiap siklus terdiri dari tahap perencanaan, pelaksanaan, observasi, dan refleksi. Subjek penelitian ini adalah siswa kelas I SDN Ngarus 02 Kecamatan Pati Kabupaten Pati Tahun Pelajaran 2020/2021, sebanyak 36 siswa terdiri dari 19 siswa laki-laki dan 13 siswa perempuan

Penelitian dilaksanakan pada semester 1 tahun pelajaran 2020/2021 yang pelaksanaannya awal bulan Oktober 2020 yaitu Pra siklus dilaksanakan pada hari Senin tanggal 5 Oktober 2020, Siklus I dilaksanakan pada hari Rabu tanggal 19 Oktober 2020 Siklus II dilaksanakan pada hari Kamis tanggal 22 Oktober 2020, Siklus III dilaksanakan hari Kamis tanggal 12 November 2020

Penelitian ini menggunakan metode deskriptif. Metode deskriptif adalah suatu penelitian yang diupayakan untuk mengamati permasalahan secara sistematis dan akurat mengenai fakta dan sifat objek tertentu (Mahmud, 2011: 100)

Data yang dianalisis berupa data kuantitatif yaitu hasil belajar tematik peserta didik. Teknik pengumpulan data menggunakan tes dan non tes.. Analisis data meliputi reduksi data, penyajian data, dan penarikan kesimpulan.

\section{HASIL DAN PEMBAHASAN}

Penelitian tindakan kelas ini penulis lakukan di SDN Ngarus 02 Kecamatan Pati Kabupaten Pati pada siswa kelas V tahun pelajaran 2020/2021. Dibantu teman supervisor 2 dalam mengumpulkan hasil observasi terhadap guru dan siswa serta hasil nilai formatif siswa untuk dilakukan analisis. Penelitian ini dilakukan dalam 4 tahapan, tahapan pertama adalah tahap pra siklus, tahap kedua adalah tahap siklus I, tahap ketiga adalah tahap siklus II dan tahap keempat siklus III. 
SHEs: Conference Series 3 (3) (2020) $353-359$

Tabel 1. Hasil Belajar Peserta Didik Setiap Siklus.

\begin{tabular}{llllll}
\hline No & Uraian & $\begin{array}{l}\text { Pra } \\
\text { Siklus }\end{array}$ & Siklus I & Siklus II & Siklus III \\
& & 69 & 73 & 74 & \\
\hline 1. & Nilai Rata-rata & 80 & 90 & 90 & 90 \\
2. & Nilai Tertinggi & 60 & 60 & 60 & 60 \\
3. & Nilai Terendah & 75 & 75 & 75 & 75 \\
4. & KKM & 6 & 16 & 19 & 27 \\
5. & Siswa Tuntas & $17 \%$ & $40 \%$ & $52 \%$ & $75 \%$ \\
6. & Persentase Ketuntasan & 30 & 20 & 17 & 9 \\
7. & Siswa Belum Tuntas & $83 \%$ & $60 \%$ & $48 \%$ & $25 \%$ \\
8. & Persentase Ketidak & & & & \\
\hline
\end{tabular}

Dari data tersebut dapat diketahui bahwa nilai yang berada di bawah KKM mencapai 30 siswa dari 36 jumlah keseluruhan siswa. Hanya 16 anak yang mendapatkan nilai sesuai atau di atas KKM. Jika diprosentasikan siswa yang tuntas hanya $75 \%$ dan $25 \%$ tidak tuntas, sedangkan nilai rata-rata kelas masih 80 sehingga msudah di atas KKM. Dapat disimpulkan hasil belajar siswa masih sudah tuntas.

Berdasarkan evalusai yang telak dilaksanakan pada Siklus I, II dan III pada materi sistem organ pencernaan manusia mengalami peningkatan kemampuan berpikir kritis dan hasil belajar. Penerapan Concept Mapping dalam pembelajaran dengan mengacu sintaknya dapat meningkatkan rata-rata dan prosentase ketuntasan siswa. Hal tersebut sejalan dengan pendapat Suprijono (2014: 7) hasil belajar adalah perubahan secara keseluruhan bukan hanya salah satu aspek yang potensi kemanusiaan saja, artinya tidak dapat dilihat secara fragmentaris atau terpisah melainkan komprehensif. Sedangkan berpikir kritis menurut Johnson (2007: 185) adalah untuk mencapai pemahaman yang mendalam. Penelitian ini juga punya relevansi dengan penelitian yang telah dilakukan Lutfi Lingga Ratih Gupita (2015), Samaita Ginting (2015) karena mempunyai variabel yang sama yaitu kemampuan kritis dan penggunaan metode Concept Mapping.

Penelitian Tindakan Kelas ini dilaksanakan dengan tujuan untuk meningkatkan kemamapuan berpikir kritis yang juga berhubungan erat dengan hasil belajar terhadap materi sistem organ pencernaan manusia pada siswa kelas $\mathrm{V}$ SD Negeri Ngarus 02 Pati.

\section{Proses Penerapan Metode Concept Mapping}

Metode Concept Mapping merupakan pengembangan dari model Kooperatif Learning. Model Kooperatif Learning sendiri merupakan model pembelajaran kolaboratif dimana siswa bertanggung jawab atas belajar mereka sendiri dan menemukan informasi mandiri untuk menjawab pertanyaan-pertanyaan yang dihadapkan pada mereka. Guru bertindak sebagai fasilisator, memberikan dukungan tetapi tidak mengarahkan kelompok ke arah hasil yang sudah disiapkan sebelumnya, pembelajaran dilihat juga dalam prosesnya.

Pada penelitian ini, kegiatan pembelajaran diarahkan terhadap metode concept mapping untuk mempermudah siswa dalam memahami materi yang luas menjadi konsep-konsep yang lebih sederhana. Selain itu proses analisis media pembelajaran baik berupa video maupun teks bacaan, terdapat proses menemukan sendiri informasi-informasi penting yang akan dibuat concept mapping. Secara tidak langsung siswa diarahkan untuk berpikir kritis. Indikator yang peneliti tentukan dalam proses peningkatan berpikir kritis telah mewakili ketercapaian target penelitian. Siswa diberikan kebebasan belajar terutama dalam mengungkapkan pendapat dengan bahasa mereke sendiri dan aktif dalam diskusi kelompok. Pada proses evaluasi, 
SHEs: Conference Series 3 (3) (2020) $353-359$

peneliti menggunakan level kognitif C4-C6 yaitu level kognitif HOTs pada Taksonomi Bloom.

2. Peningkatan hasil belajar

Berdasarkan evalusai yang telak dilaksanakan pada Siklus I, II dan III pada materi sistem organ pencernaan manusia mengalami peningkatan kemampuan berpikir kritis dan hasil belajar. Penerapan Concept Mapping dalam pembelajaran dengan mengacu sintaknya dapat meningkatkan rata-rata dan prosentase ketuntasan siswa. Hal tersebut sejalan dengan pendapat Suprijono (2014: 7)

Agar dapat mengetahui target dan pencapaian dalam penelitian ini, peneliti menjabarkan hasil belajar dan kemampuan berpikir kritis dalam bentuk tabel 4.15 sebagai berikut :

1. Hasil belajar

Tabel 2. Hasil evaluasi siswa

\begin{tabular}{|c|c|c|c|c|c|c|c|c|}
\hline \multirow{2}{*}{ Perubahan } & \multirow{2}{*}{ Indikator } & \multirow{2}{*}{$\begin{array}{l}\text { Pra } \\
\text { Siklus }\end{array}$} & \multicolumn{2}{|c|}{ Evaluasi Siklus I } & \multicolumn{2}{|c|}{ Evaluasi Siklus II } & \multicolumn{2}{|c|}{ Evaluasi Siklus III } \\
\hline & & & Target & Capaian & Target & capaian & Target & Capaian \\
\hline Hasil & $\begin{array}{l}\text { Nilai Rata- } \\
\text { rata siswa }\end{array}$ & 69 & 75 & 73 & 75 & 74 & 75 & 80 \\
\hline Belajar & $\begin{array}{l}\text { Prosentase } \\
\text { ketuntasan } \\
\text { siswa }\end{array}$ & $17 \%$ & $75 \%$ & $40 \%$ & $75 \%$ & $52 \%$ & $75 \%$ & $75 \%$ \\
\hline
\end{tabular}

Hasil belajar siswa yang diperoleh dari setiap evaluasi rata-rata mengalami peningkatan. Peningkatan dapat dilihat dari pra siklus dengan rata-rata 69 menjadi 73 di siklus I sehingga terjadi peningkatan $23 \%$. Sedangkan pada siklus I hasil evaluasi diperoleh rata-rata 73 menjadi 74 pada siklus II. Pada tahap ini terjadi peningkatan $12 \%$ dan pada siklus III mengalami peningkatan $23 \%$.

2. Kemampuan Berpikir Kritis

Peneliti melakukan pengamatan untuk mendukung data peningkatan berpikir kritis dari hasil kuisioner. Pengataman dilakukan di setiap pertemuan selama tiga siklus. Hasil pengamatan tersebut terdapat pada tabel berikut ini :

Tabel 3. Hasil pengamatan Berpikir Kritis

\begin{tabular}{|c|c|c|c|c|c|c|c|c|c|c|c|}
\hline \multirow[b]{2}{*}{ Perubahan } & \multirow[b]{2}{*}{ Indikator } & \multicolumn{2}{|c|}{$\begin{array}{c}\text { Pra } \\
\text { Siklus }\end{array}$} & \multicolumn{2}{|c|}{ Siklus I } & \multicolumn{2}{|c|}{ Siklus II } & \multicolumn{2}{|c|}{ Siklus III } & \multirow{2}{*}{$\begin{array}{l}\text { Rata- } \\
\text { rata }\end{array}$} & \multirow{2}{*}{ Kriteria } \\
\hline & & Skor & Kriteria & Skor & Kriteria & Skor & Kriteria & Skor & Kriteria & & \\
\hline \multirow{7}{*}{ Kemampuan } & \multirow{2}{*}{$\begin{array}{l}\text { Menganalisis } \\
\text { argumen }\end{array}$} & \multirow[b]{2}{*}{63,3} & Tidak & \multirow[b]{2}{*}{67} & Cukup & \multirow[b]{2}{*}{68} & Cukup & \multirow[b]{2}{*}{69} & Cukup & \multirow[b]{2}{*}{68} & Cukup \\
\hline & & & Kritis & & Kritis & & Kritis & & Kritis & & Kritis \\
\hline & \multirow[b]{2}{*}{ Mampu bertanya } & \multirow[b]{2}{*}{60,2} & Tidak & \multirow[b]{2}{*}{62} & Cukup & \multirow[b]{2}{*}{62} & Cukup & \multirow[b]{2}{*}{67} & Cukup & \multirow[b]{2}{*}{64} & Cukup \\
\hline & & & Kritis & & Kritis & & Kritis & & Kritis & & Kritis \\
\hline & \multirow{2}{*}{$\begin{array}{l}\text { Mampu } \\
\text { menjawab } \\
\text { pertanyaan }\end{array}$} & \multirow[b]{2}{*}{63,0} & Tidak & \multirow[b]{2}{*}{64} & Cukup & \multirow[b]{2}{*}{66} & Cukup & & Cukup & \multirow[b]{2}{*}{65} & Cukup \\
\hline & & & Kritis & & Kritis & & Kritis & 65 & Kritis & & Kritis \\
\hline & Memecahkan & 63,44 & Tidak & 61 & Tidak & 67 & Tidak & 68 & Cukup & 64 & Cukup \\
\hline
\end{tabular}


Workshop Nasional Penguatan Kompetensi Guru Sekolah Dasar 2020

SHEs: Conference Series 3 (3) (2020) $353-359$

\begin{tabular}{|c|c|c|c|c|c|c|c|c|c|c|}
\hline masalah & & Kritis & & Kritis & & Kritis & & Kritis & & Kritis \\
\hline $\begin{array}{l}\text { Membuat } \\
\text { kesimpulan }\end{array}$ & 64,5 & $\begin{array}{l}\text { Tidak } \\
\text { Kritis }\end{array}$ & 67 & $\begin{array}{l}\text { Cukup } \\
\text { Kritis }\end{array}$ & 66 & $\begin{array}{l}\text { Cukup } \\
\text { Kritis }\end{array}$ & 68 & $\begin{array}{l}\text { Cukup } \\
\text { Kritis }\end{array}$ & 65 & $\begin{array}{l}\text { Cukup } \\
\text { Kritis }\end{array}$ \\
\hline $\begin{array}{l}\text { Ketrampilan } \\
\text { mengevaluasi } \\
\text { dan menilai hasil } \\
\text { dari pengamatan }\end{array}$ & 64,2 & $\begin{array}{l}\text { Cukup } \\
\text { Kritis }\end{array}$ & 66 & $\begin{array}{l}\text { Cukup } \\
\text { Kritis }\end{array}$ & 64 & $\begin{array}{l}\text { Cukup } \\
\text { Kritis }\end{array}$ & 65 & $\begin{array}{l}\text { Cukup } \\
\text { Kritis }\end{array}$ & 65 & $\begin{array}{c}\text { Cukup } \\
\text { Kritis }\end{array}$ \\
\hline Rata-rata keseluruhan & 63,1 & Tidak & 64,5 & Cukup & 66 & Cukup & 67 & Cukup & & \\
\hline Prosentase & $63 \%$ & Kritis & $65 \%$ & Kritis & $66 \%$ & Kritis & $67 \%$ & Kritis & & \\
\hline
\end{tabular}

Berdasarkan tabel tersebut terdapat 6 indikator yang menjadi acuan dalam meningkatkan kemampuan berpikir kritis. Pada pra siklus rata-rata keseluruhan indikator memperoleh skor 63,1 yang menunjukan tidak kritis. Pada siklus I memperoleh skor 64,5 (cukup kritis). Pada siklus II memperoleh skor 66 yang menunjukkan kemampuan berpikir cukup kritis. Pada tahap ini mengalami peningkatan 1,5 atau $1 \%$. Pada siklus III memperoleh skor 67 yang menunjukkan meningkatan kemampuan berpikir kritis. Dibandingkan pada siklus II, kemampuan berpikir kritis pada siklus III pun mengalami peningkatan.

\section{SIMPULAN}

Penerapan Metode Concept Mapping dapat meningkatkan hasil belajar siswa tentang materi Sistem Organ Pencernaan Manusia. Sebagai indikasinya terjadi peningkatan hasil belajar siswa yang ditunjukkan dengan perolehan rata-rata nilai-nilai formatif siswa dari pra siklus 69, siklus I 73, siklus II 74 dan siklus III 80 terjadi peningkatan rata-rata sebesar 11 . Sedangkan ketuntasan belajar pada pra siklus $17 \%$, siklus I 40\%, siklus II 52\% dan siklus III 75\% terjadi peningkatan sebesar 58\%.

Penerapan Metode Concept Mapping juga meningkatkan kemampuan berpikir kritis yang ditunjukkan dengan perolehan skor dari pra siklus 63, siklus I 65 siklus II 66 dan siklus III 67 terjadi peningkatan sebesar 4. Sedangkan prosentasenya pada pra siklus $63 \%$ siklus I $65 \%$ siklus II 66\% dan siklus III 67\% terjadi peningkatan $4 \%$. Kemampuan berpikir kritis mengalami peningkatan dari tidak kritis menjadi cukup kritis.

\section{DAFTAR PUSTAKA}

Anitah, Sri. 2008. Strategi Belajar Mengajar. Jakarta : Rineka Cipta.

Anonim. 2011. Kajian Pustaka Metode Pembelajaran. http://eprints.uny.ac.id/

(diakses tanggal 13 Oktober 2020)

Arikunto, S et all. 2016. Penelitian Tindakan Kelas. Jakarta: Bumi Aksara.

Arikunto, S. 2010. Prosedur Penelitian: suatu pendekatan praktek. Jakarta : Rineka Cipta.

Arum Puri Suryandari. 2017. Jurnal penggunaan metode pembelajaran mind mapping dan media CD interaktif system gerak manusia terhadap penguasaan konsep dan kemampuan berpikir kritis siswa SMP. (1) $1: 1$

Dimyati \& Mujiono. 2006. Belajar dan Pembelajaran. Jakarta : PT Rineka Cipta. 
Farqiyatur Ramadhan, Susriyati Mahanal, Siti Zubaidah. 2016. Jurnal potensi Remap STAD untuk meningkatkan ketrampilan berfikir kritis siswa. 13(1) : 203-208

Fisher, A. 2008. Berpikir Kritis Sebuah Pengantar. Jakarta: Erlangga.

Hartono, Agung. Sunarto. 2008. Perkembangan Peserta Didik. Jakarta : Rineka Cipta.

Johnson, Elaine B. 2011. Contextual Teaching and Learning; menjadikan kegiatan belajar mengajar mengasyikkan dan bermakna. Bandung: Khaifa.

Nainggolan, Suriani, Sianturi. 2017.Jurnal analisis kemampuan berpikir kritis siswa pada materi pokok sistem pencernaan manusia_di kelas XI IPA SMA Swasta YAPIM Biru-Biru. 6 (3) : 174-178

Riyana, Cepi. Susilana, Rudi. 2011. Media Pembelajaran. Bandung : Wacana Prima.

Sardiman. 2014. Interaksi dan Motivasi Belajar Mengajar. Jakarta : RajaGrafindo Persada.

Suhardjono, Supardi. 2013. Strategi Menyusun Penelitian Tindakan Kelas. Yogyakarta : Andi Offset.

Suparlan. 2005. Menjadi Guru Efektif. Yogyakarta : Hikayat Publishing.

Suprijono, Agus. 2014. Cooperative Learning, Teori dan Aplikasi PAIKEM. Yogyakarta : Pustaka Belajar. 